\title{
Energy, land and water nexus in Sri Lanka's Mahaweli basin
}

\author{
Michael Richard Chegwin MA, MSC, MBA, CEng, MICE \\ Principal Consultant, Lahmeyer International $\mathrm{GmbH}$, Bad Vilbel, Hesse, \\ Germany (corresponding author: michael.chegwin@de.lahmeyer.com)
}

\author{
Sisira Kumara BSc (Eng), MSc (WRD), PG Dip, CEng (SL) \\ Secretary, Ministry of Irrigation and Water Resources, Colombo, Sri Lanka \\ (secretarymiwrm@gmail.com)
}

The Mahaweli Water Security Investment Program, financed by the Asian Development Bank and the Government of Sri Lanka, aims to complete the Mahaweli Development Program, started in the 1970s to improve farmer incomes, food security, equity between different parts of the country, public health, and domestic, municipal and industrial water supplies. Up to 900 million $\mathrm{m}^{3}$ of water will be transferred annually through canals, reservoirs and tunnels from the Mahaweli River to the water-scarce north and north-west, where smallholder farmers have traditionally practised single-season rice cultivation. The transfer will facilitate cultivation of a second, diversified, crop and must be shared with competing consumptive demands, as well as meeting daily peak energy demands through releases for hydropower. The paper comprises a briefing exploring how the nexus is to be managed with the help of strengthened integrated water resources management, complex decision-support systems, institutional capacity development, strategic environmental analysis and consensus winning.

\section{Introduction}

Energy, land and water in Sri Lanka form a nexus of which the complexity is increasing with the addition of storage and conveyance infrastructure. Formerly, hydropower contributed much of the total energy generated in the country, resulting in tradeoffs between irrigation and hydropower energy generation, although mainly at times of water shortage. More recently, the country's major hydropower plants - some $70 \%$ of which are located on the country's largest river, the Mahaweli Ganga are used mainly for meeting peak morning and evening municipal and domestic demands, with base load generated by thermal stations that cannot react quickly to demand peaks. The emphasis has therefore shifted from competition between the requirements for irrigation/flood control and the monetary value of energy to a focus on the ability of the network to meet demands as they arise, without detrimental effects on other competing water users. Figure 1 shows the Mahaweli River and the main irrigation areas and hydropower facilities.

Competing demands are managed through a Water Management Secretariat (WMS), which prepares a seasonal operation plan (SOP) prior to each of the two growing seasons, Maha and Yala, based on the then-current available storages and demand forecasts. The result is used to provide farmers in different regions with guidance on the likely maximum area that will be practicable to irrigate. There are multiple levels of planning and information flows. During the season, the decision makers meet on a weekly basis and adjust reservoir operations according to needs through a process of negotiation among representatives of different user groups. While the process is participative, years of experience and the tacit knowledge of senior members of WMS are essential for judging the impacts at different locations of decisions on reservoir releases. Since no national water policy has been enacted, allocation is largely based on operative decisions.

While substantial amounts of water are still flowing from the Mahaweli to the ocean near Trincomalee on the east coast, management of demands is, while challenging, not as complex as it will be in the future. Precisely because a significant amount of water is still flowing to the sea, the scarcity of water in parts of the country present the potential for increases in livelihood and improved food security through higher cropping intensities, relief of municipal and industrial water shortages, and better health by substitution with surface water of polluted groundwater, which is thought to be responsible for chronic kidney disease (CKD) that afflicts most of the people in the north and north-west of the country.

Addressing these additional demands requires the construction of conveyance and storage infrastructure, comprising canals, tunnels, pumping facilities and reservoirs. The Mahaweli Development Programme (MDP), which started in the early 1970s with the construction of the Polgolla tunnel for diverting water from the Mahaweli near the town of Kandy to irrigation schemes, has the ultimate goal of conveying excess water to the drier north and north-west of the island through the construction of further large-scale civil engineering infrastructure, for equitable distribution among all the basins supplied. Progress since the 1970s includes the construction of the major irrigation and hydropower dams and large irrigation systems as well as creation of important social infrastructure. The Mahaweli Water Security Investment Program (MWSIP) comprises the first phase of the completion of the MDP. 
Energy, land and water nexus in

Sri Lanka's Mahaweli basin

Chegwin and Kumara

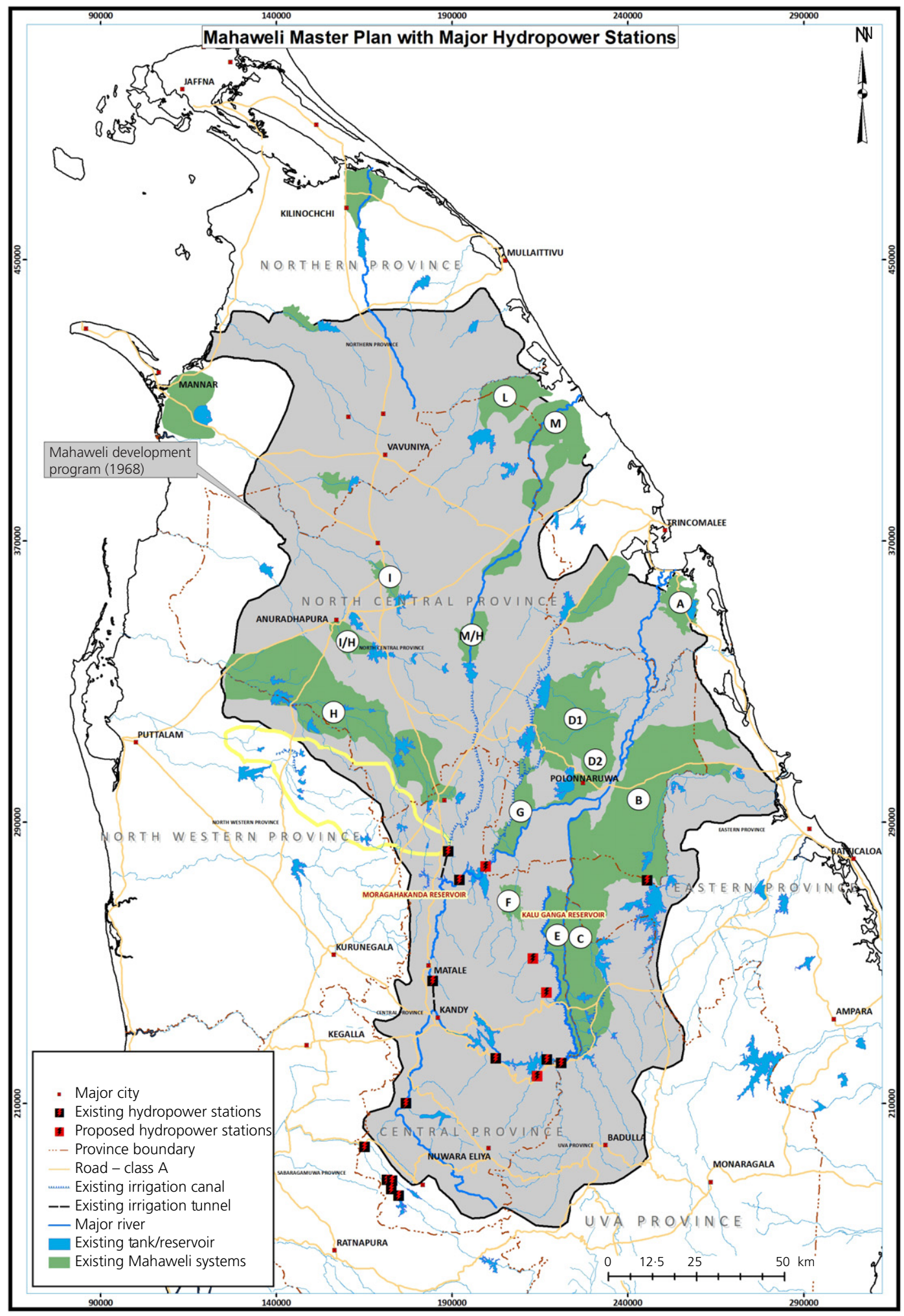

Figure 1. Mahaweli Ganga and main irrigation schemes and hydropower plants. A full-colour version of this figure can be found on the ICE Virtual Library (www.icevirtuallibrary.com) 
Addressing the nexus effectively can be achieved neither by infrastructure construction alone nor with any other single methodology. Rather it demands a wide range of approaches and a recognition that these approaches must remain flexible and adaptable. Major water transfers are fraught with potential conflicts, having a range of sources - from ethnic differences and prior water rights to economic deprivation and possible environmental damage. Some commentators have even raised the spectre of water wars should such transfers be implemented (and depending on how this is done); others believe there are comparable threats to internal security if water is not more equitably distributed. In addition, concerns over the country's ability to meet peak energy demands are strongly linked to maximising discharges through existing and planned hydropower facilities. Whatever the extent of the redistribution, it will require responsive designs founded on good data, sound assumptions and careful, sensitive management. The need for care and applied expertise will be more pronounced the more widely the water is distributed and the less excess water there is in the system to buffer shortages. Such developments will need technical, social and institutional changes that are already experiencing resistance and generating controversy among different interest groups.

Infrastructure planning is therefore being accompanied by intensive programmes of communication, awareness raising and consensus-seeking, broad institutional capacity building, strategic environmental assessment and the introduction of sophisticated decision-support systems (DSSs) for water allocation, as well as the implementation of initiatives for improving water productivity and more profound introduction of the principles of integrated water resources management.

For managing and guiding this challenging initiative Sri Lanka's Ministry of Mahaweli Development and Environment (MMDE), supported by the Mahaweli Authority of Sri Lanka (MASL) and the Department of Irrigation (DOI), has set up a Program Management Unit (PMU) and three Project Implementation Units (PIUs) with a staff of specialists in a wide range of disciplines. These units are assisted through the appointment by MMDE of a Program Management, Design and Supervision Consultant (PMDSC). The authors are senior representatives of these organisations.

This paper begins (Section 2) with some background description of the water resources of Sri Lanka, the demands on them and how they have been managed in the past. Section 3 describes the competition between demands for energy and food production and the options for addressing these tensions, while Section 4 outlines the difficulties facing decision-makers. The application of multi-criteria analysis (MCA) as an approach to managing diverse stakeholder objectives is illustrated in Section 5. Other components of the ongoing work are discussed in Sections 6 and 7. Section 8 draws some tentative conclusions from the work to date.

\section{Background}

The distribution of Sri Lanka's rainfall is skewed in time and space. Most rain falls during two distinct monsoons: during December to February ('Maha') and May to September ('Yala') and the majority falls in the south-west and central highlands. Contrasting annual rainfall exceeding $5000 \mathrm{~mm}$ in the highlands, the country's lowlands are dry, particularly in the 'northern dry zone' region where the mean figure is less than $1500 \mathrm{~mm}$, with regular droughts. Water security in the region could further deteriorate due to the growing population and anticipated climate change (which foresees higher temperatures and increased differential between dry and wet zone rainfall amounts). The population of the country is predicted to go on growing from a figure of $20.4 \mathrm{~m}$ according to the 2012 census to a peak of some $22.0 \mathrm{~m}$ in 2031 as reported by PMDSC (2017).

Local communities have historically managed water stress by constructing many small cascade systems of reservoirs ('tanks'), transfer canals and irrigation schemes, which have provided supplementary irrigation for a single paddy rice crop each year and limited storage for drinking water. Many communities rely for drinking on groundwater, some of which is contaminated, causing high incidences of CKD. Social and economic development is correspondingly suppressed and the gross regional domestic product per capita in the northern dry zone is about $30 \%$ lower than in other regions. The MDP aims to address these inequities although the enhancement of physical and institutional infrastructure for equitably redistributing water for increased agricultural productivity, improvement of access to safe drinking water and encouragement of economic growth, while avoiding injustice being caused to any presently irrigated or future served basin.

\section{Trade-offs}

Zeng et al. (2017) found that 54\% of global installed hydropower capacity (around $507000 \mathrm{MW}$ ) competes with irrigation, while only $8 \%$ of global installed hydropower capacity (around $79000 \mathrm{MW}$ ) complements irrigation. Sri Lanka has extended experience of the competition for water among key users.

The concept of trade-off frontiers in respect of food, energy and water in Sri Lanka was developed by Perrone and Hornberger (2016: p. 2): 'A tradeoff frontier... is used traditionally to show the compromise between two outputs given a set number of inputs: all else equal production of one output cannot increase without decreasing the other output's production. The outcome is efficient if it lies on the frontier'. The authors 
examined competition between energy generation and paddy production using the current infrastructure of the Mahaweli basin, simulating diversions of from 0 to $100 \%$ of river flows at Polgolla to irrigation schemes supplied by this diversion by way of small and mini-hydropower facilities. The results indicated that maximum hydropower energy production would be achieved for zero diversion at Polgolla (because all river water would then be turbined through the larger-capacity plants on the main river), while maximum paddy production would be achieved for diversions at Polgolla of between 50 and 100\% (about 2/3 of currently irrigated paddy lands are supplied from the diverted proportion, compared with $1 / 3$ supplied from the main river downstream of the diversion point at Polgolla). Reported management as practised was that - depending on season - the diversion was between 49 and $60 \%$, with paddy production and hydropower energy production lying close to the trade-off frontier when large paddy areas were cultivated.

Further diversion of water from the main Mahaweli (which is to be supplemented by development of storages on other Mahaweli river basin tributaries) to augment domestic, municipal and industrial (DMI) water supplies and irrigation in the north and north-west will add significantly to the complexity of decision making on reservoir operations. With irrigated lands in the north more than $100 \mathrm{~km}$ away from the source, timing aspects will also play a critical role in managing this water. One key decision to be made before deciding on the extent of, and developing, the finally required physical infrastructure will be the route(s) to be taken by the diverted water.

There are two main options (Figure 2): (a) route 1, the Kotmale-Polgolla transfer route or 'KPTR', comprising additional diversion at Polgolla through the construction of a second tunnel, accompanied by the raising of Kotmale dam one of the main hydropower facilities (installed capacity $201 \mathrm{MW}$ ) in the upstream part of the Mahaweli catchment; and $(b)$ route 2, the Randenigala-Kalu Ganga transfer canal or 'RKTC', which foresees no increase in the current diversion at Polgolla and the construction of a diversion tunnel to transfer water from the Randenigala reservoir to the Kalu Ganga reservoir (currently under construction), collecting en route supplementary water from two smaller catchments. The second option would be accompanied by the diversion of water from the Uma Oya River in the south to outfall in Randenigala reservoir rather than in the downstream Rantembe reservoir as at present, so that waters not transferred north could also be turbined through the Randenigala hydropower station to compensate for transferred water.

Both route options terminate at the Moragahakanda reservoir (Figure 3), which has recently been inaugurated. In both cases, a tunnel connection between the Kalu Ganga and Moragahakanda reservoirs is foreseen and is likely to start construction during 2018. To achieve the proposed transfers to the north both route options would also require two-stage pumping from the lower Mahaweli to an existing distribution canal located to the north-east of Moragahakanda reservoir (Figure 4). Pumping would be required to supplement water from one of the Mahaweli's main tributaries (Amban Ganga) used for current and proposed irrigation in the Polonnaruwa and Kantale areas, so that water can be transferred northwards from Moragahakanda (located on the Amban Ganga) without detrimental effects on those areas.

It became clear when assessing these two route options that an economic comparison alone (e.g. using the concepts of trade-off frontiers) would not address fully the concerns of the multiple stakeholders with an interest in the outcome of the decision. Apart from the competition between irrigation and energy generation (both total and peaking), the routes are characterised by widely different environmental and social impacts. The final decision on the route to be selected, while imminent, has yet to be taken and some of the actions taken to address stakeholders' concerns are outlined below.

\section{Resistance to change}

Opponents of the further development of MDP cite current shortages of water at various times: how, they ask, can water be taken away from where it is already scarce? However, the feasibility of redistributing water depends on the addition of reservoirs to store water that flows to the sea, especially during times of plentiful rain, and interconnections among these storages to facilitate the transfer of water to where it is needed, when it is needed. It also depends partly on achieving efficiency increases in water use. Visualising a future in which water is indeed sufficient for distributing more widely in the dry season (when there is less water everywhere) as a result of the existence of these storages and interconnections is not easy, especially for opponents to redistribution. Some of these opponents may have little faith in studies, models or simulations and may tend to present valid perceptions of the present situation as proof of the folly of further attempts at redistribution.

Concern has also been expressed by the electricity providers, who note that any diversion from the Mahaweli for water distribution to other parts of the country takes out of the main river water that would otherwise have been available for turbining further downstream to meet peak consumer energy demands.

The location on the Mahaweli that is furthest downstream (i.e. with the most main hydropower schemes upstream of that location) while still allowing gravity diversion to the north, lies at Randenigala reservoir, a hydropower facility with an installed capacity of $126 \mathrm{MW}$. One more hydropower 


\section{Energy}

Volume 171 Issue EN3
Energy, land and water nexus in

Sri Lanka's Mahaweli basin

Chegwin and Kumara

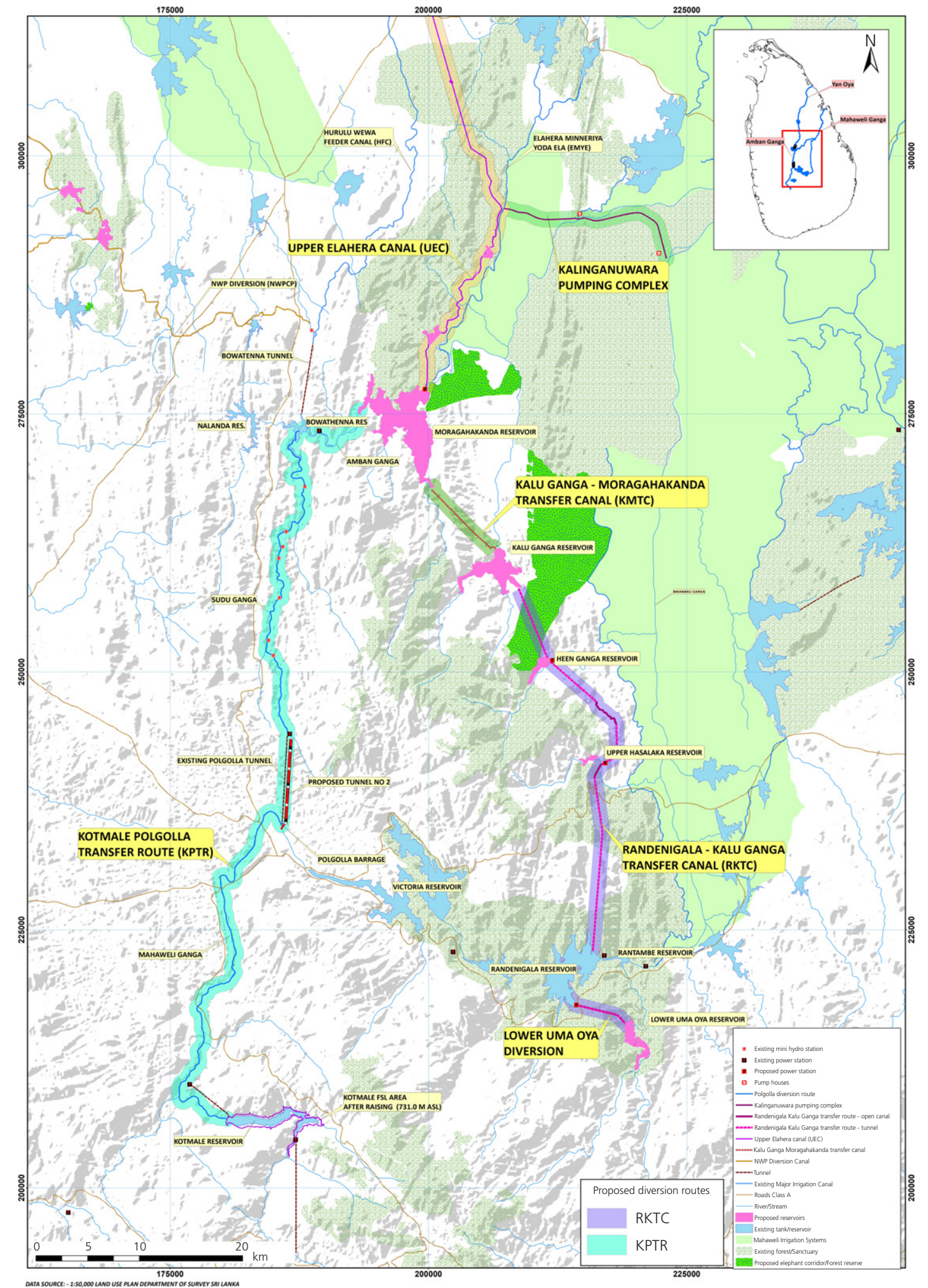

Figure 2. Two main route options for diversions from Mahaweli. A full-colour version of this figure can be found on the ICE Virtual Library (www.icevirtuallibrary.com) 
Energy, land and water nexus in Sri Lanka's Mahaweli basin

Chegwin and Kumara

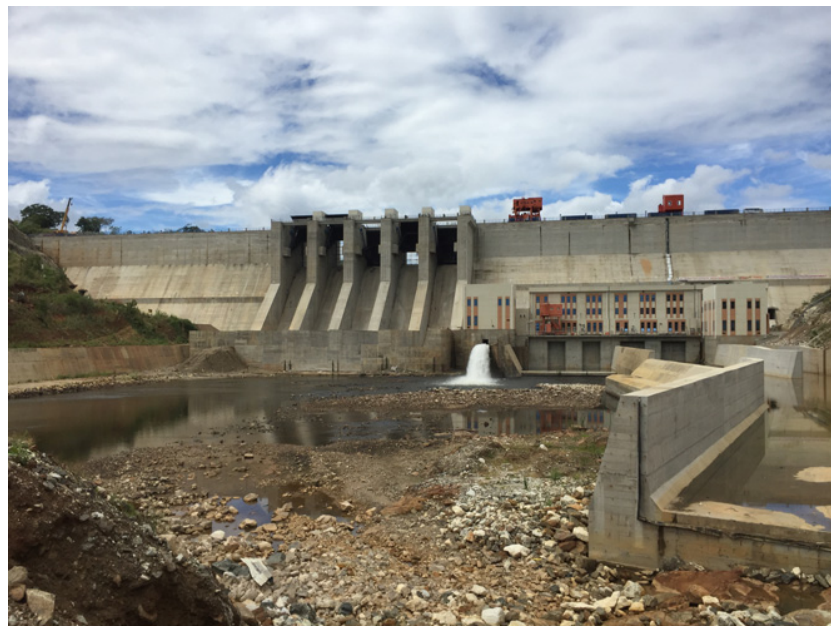

Figure 3. Moragahakanda dam showing the initial metres of the northern conveyor (upper Elahera canal)

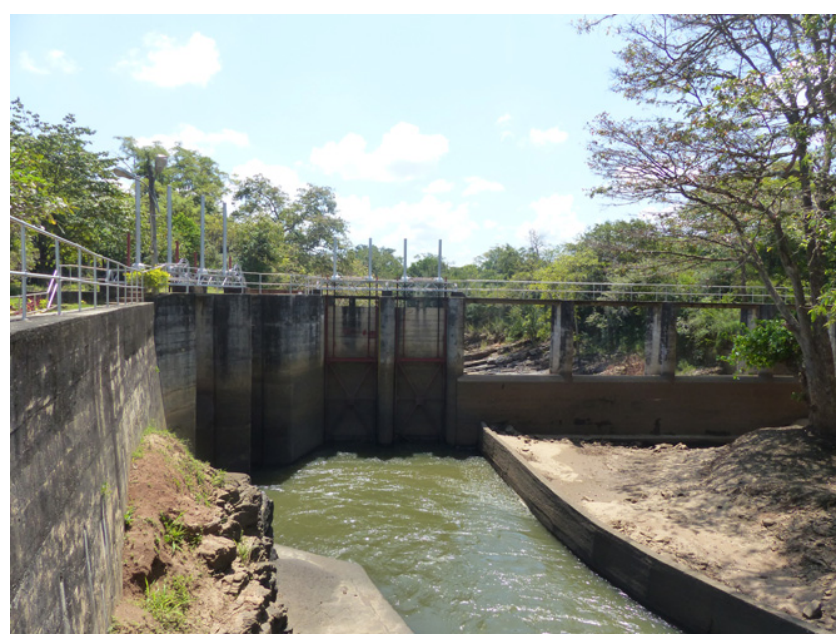

Figure 4. Elahera Minneriya Yoda Ela canal headworks

facility, Rantembe (installed capacity $52 \mathrm{MW}$ ), is situated downstream of this point. Mitigation of the energy loss resulting from transfers northwards of water that would otherwise be turbined is proposed by diverting flows from the Uma Oya River from their current outfall in Rantembe (the last hydropower station in the cascade) to a new outfall in Randenigala (thus allowing this water to be turbined through an additional hydropower station). Nevertheless, there exist proponents of an arrangement that would allow all water planned for transfer to be turbined first through all hydropower stations, so as to retain the maximum peaking capability of the hydropower plants, with later pumping up of the transfer water from the lower Mahaweli using power from thermal stations. The pumping of water from the lower Mahaweli is an important

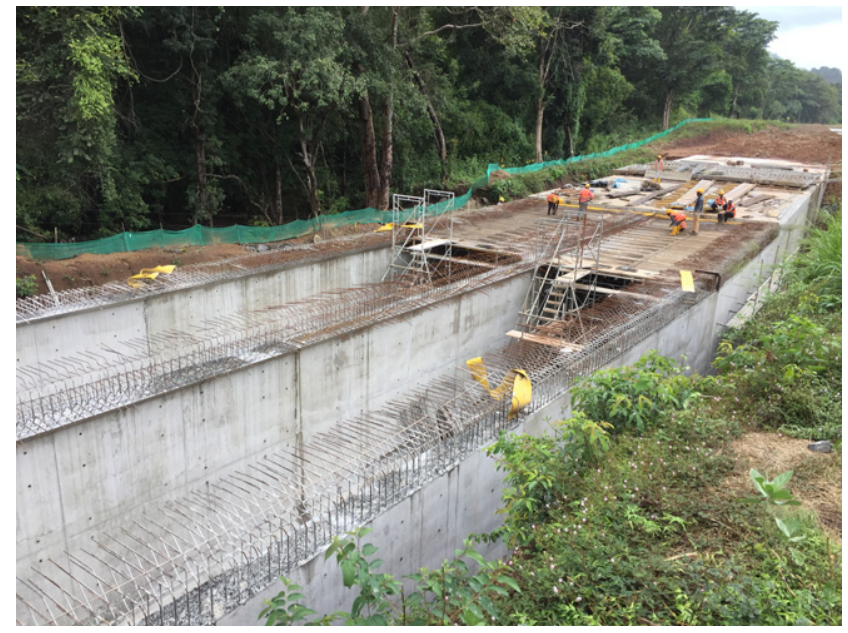

Figure 5. Twin rectangular conduit under construction on upper Elahera canal

component of the overall foreseen transfer, but has physical limits and potentially serious environmental impacts, and its realisation currently has no fixed programme.

Further progress with the MDP is therefore far more complex than simply constructing large-scale physical infrastructure, challenging although that already has proved to be: implementation of the MWSIP, the first phase of completing the MDP, will require the construction of some $230 \mathrm{~km}$ of open and covered canal, nearly $40 \mathrm{~km}$ of tunnels up to $8 \mathrm{~m}$ in internal diameter, completion of Kalu Ganga and Moragahakanda reservoirs, construction of two large new reservoirs and the raising of existing reservoir embankments. While work has already started on the construction of this infrastructure (Figure 5), controversy remains over its possible final extent under future phases and the existence of a very wide range of stakeholders from many different sectors makes the gaining of consensus on the way forward a significant challenge.

\section{Decision-support systems}

\subsection{Multi-criteria analysis}

While route selection for the transfer of water from the Mahaweli to Moragahakanda reservoir (see Section 3) has still to be finalised, a first step has been taken to explore trade-offs and impacts, and to seek consensus on the selection using a participative process of MCA combined with mathematical simulation of water transfer and its impact on agricultural production and hydroelectric energy generation. Software for water-allocation simulation is currently used for preparing seasonal operation plans (SOPs) (see Section 1) for the existing infrastructure and was developed to include proposed future infrastructure additions that would facilitate water transfer 
northwards. The software uses a monthly time step and the results have subsequently been broadly confirmed by applying different software that uses a daily time step (see Section 5.2), although this analysis still has to be finalised.

The route options described in Section 3 were examined using multiple criteria in consultation with representatives of the main stakeholder groups, who identified the criteria and then assigned weights (assessments of importance) to them. At the first stakeholder workshop held in February 2016, 84 stakeholders from more than 20 organisations and institutions identified 41 criteria on which the routes should be scored. The identified criteria are listed in Appendix 1. The criteria were subsequently weighted by the stakeholders, who also formed selfnominated interest groups (agriculture, power generation, hydrology, environment and social impact, as well as a general group).

For the purposes of comparison, two scenarios for route 1, the KPTR, were adopted: (a) Version 1 (V1), sustaining the design duty at the lower Mahaweli pump station (PS), which results in a lower supply reliability; and (b) Version 2 (V2), increased pumping (above the design duty assumed in $(a)$ ) to attain comparable supply reliability to that provided by route 2 , RKTC, but with additional costs, both capital for additional pumps and rising mains, and for operation and maintenance. In addition, a variant of the KPTR (referred to as Version 3 (V3)) was requested by a key stakeholder, which is a combination of an optimally heightened Kotmale dam, as well as construction of two of the RKTC reservoirs (Hasalaka Oya and Heen Ganga) and the associated transfer canal to the Kalu Ganga reservoir, but without the link from Randenigala.

\subsubsection{Criteria valuation}

The 41 comparison criteria provided by stakeholders were categorised into three groups ('economic', 'environment' and 'social'), as described below. Fourteen criteria were grouped within the economic category; another 14 within the environment category; eight were considered to cover social issues; and five criteria had a mix of more than one category characteristic.

The MCA approach then required that quantitative or qualitative values be associated with these criteria. This aspect of MCA is known as 'scoring', and involves filling in the cells of a matrix where the comparison criteria are placed on the $Y$-axis, and the route options on the $X$-axis.

The way in which the criteria were scored varied between criteria and group, depending on the criterion type (whether measured quantitatively or qualitatively), scope of the work and availability of information and data. The level of information and scope varied between the two options. The approaches to the assessments included field inspections of the key locations, rapid ecological surveys for collection of information on flora and fauna, meetings with local social stakeholders, collection of information on populations and updating of quantities and costs.

\subsubsection{ECONOMIC}

The economic criteria included $(a)$ the water and energy criteria and $(b)$ the capital and operating and maintenance costs for the key water infrastructure for the two options. The water and energy balance is an important and integral feature of not only the MWSIP but the whole Mahaweli system. The completion of the MDP is to be designed for the transfer of currently unallocated waters from the Mahaweli Ganga to the north, at the same time minimising the impacts on power generation as well as sustaining environmental flows, maintaining equity in all basins involved. Stakeholders identified nine criteria related to water transfers and the impacts of the program on energy generation. Both route options impact on current levels of energy generation, although to different extents.

\subsubsection{ENVIRONMENT}

These criteria covered a range of environmental issues, such as impacts on habitats, endangered species, human-elephant conflict, elephant corridors and groundwater. The rapid ecological surveys in March 2016 collected information on habitats, flora and fauna at potential impact sites. For route 1 KPTR, they include the Kotmale reservoir inundation area, tunnel portals and disposal sites for tunnel spoil for the second Polgolla tunnel, as well as changes to the aquatic habitats of the Mahaweli River and of the main watercourse downstream of the Polgolla tunnel. For route 2 RKTC, the impact areas include tunnel portals, disposal sites for tunnel spoil, 'level crossings' (i.e. online storages) and inundation areas of new reservoirs.

The additional pumping from the lower Mahaweli required for the KPTR option (for V1 and V3) to achieve the required transfer volume and reliability (to meet MWSIP needs), would adversely impact on downstream users and environment, due to river flows falling below minimum environmental flows for up to 4 months.

\subsubsection{SOCIAL}

The assessment included site inspections and reconnaissance surveys of the Kotmale reservoir, Polgolla tunnel alignment and its downstream watercourse. Social impacts differ substantially between the two routes. For RKTC the route is sparsely populated and therefore the number of affected people is low: less than 100 directly and 400 indirectly. For the KPTR, the second Polgolla tunnel and its downstream watercourse are located in densely populated areas, and therefore potentially a large population would be affected. Groundwater drawdown 
affecting wells, structures and agriculture arising from tunnel construction at a new hydropower facility on a tributary of the Mahaweli has led to extreme caution with respect to new tunnel construction, especially in populated areas.

\subsubsection{MCA results}

The computations were completed for three 'runs', that is, the comparison of route $2, \mathrm{RKTC}$, with the three versions of route 1 and KPTR. The water and power simulation results and option costs (all classified as 'economic') for these comparisons are described in more detail in Appendices 2 and 3.

For MCA analysis, each of the run results was recorded for two different situations. The first situation was one in which all 41 criteria were considered on their own merits, and without assigning them to one of the criteria categories (i.e. economic, environment or social). This situation was referred to as computation with 'original data'.

In the second situation, computations were based on normalising the three categories of criteria so that, for example, the larger number of environmental and economic criteria did not unduly weigh the computation, given that there were only five social criteria. This form of data presentation represents a response during recent years by environmentalists and social justice advocates to the traditional profit-and-loss-based 'bottom line' cost-benefit analysis, and in this MCA exercise the results are termed 'triple bottom line' (TBL) data (Annandale and Lantzke, 2000).

Figure 6 shows the comparison of route 2, RKTC, with three versions of route $1, \mathrm{KPTR}$. V1 of KPTR is the basic route option, in which pumping from the lower Mahaweli is maintained at the same rate as for RKTC (and results in more severe irrigation deficits than for RKTC). In V2, pumping from the lower river is increased to achieve the same irrigation reliability as for RKTC. In V3, the first part of the tunnel linking Randenigala reservoir to Kalu Ganga reservoir is omitted (this version is preferred by the Ceylon Electricity Board because it takes away less water from the turbines at Randenigala and Rantambe hydropower facilities, which they consider essential for meeting peak demands). In all the figures, the comparison is shown for each interest group for both the 'original' data and for the TBL data. This approach allows for sensitivity testing. The figures on the $Y$-axis represent the percentage of weights where one option is better than the other.

\subsubsection{Conclusions}

The preliminary conclusion based on use of the monthly timestep model for simulating transfers and associated impacts on irrigation and power generation is that the outcome appears extremely 'robust', for route 2 RKTC conveyance option.
Regardless of the interest group weighting, or whether the computation is undertaken using 'original data' or 'TBL data', the route 2 RKTC option ranks highest in all cases.

This conclusion is now being verified - or modified if appropriate - by re-running the transfer simulations using the daily time-step model that is described in Section 5.2. The results may therefore be regarded as preliminary, although the robustness of the findings suggests that the refinement using daily inflows and daily time steps is unlikely to change the ranking of the routes.

\subsection{Simulation models}

Currently, SOPs are prepared using water-allocation optimisation software developed about 30 years ago, which has given reliable results over the years. The software utilises a least-cost optimisation algorithm to simulate and predict reservoir operations with monthly time steps. The maximum number of 'nodes' that can be handled by the software has been reached in simplified simulations of the future infrastructure, and more detailed representation of future arrangements will require an increased number of nodes.

While existing models and tools worked sufficiently well under average conditions for seasonal planning purposes considering the present system conditions (i.e. reservoir water levels) and applying time series of historical data, the requirements for weekly and daily operation have increased, considering shortterm adjustments of irrigation requirements due to actual rainfall conditions, maintenance works, gate failures, the shift in hydropower generation from base load to peak load and flood management. Monthly time steps are therefore no longer considered adequate for efficient management and for meeting system and operational demands. A daily time step is therefore to be used, including for confirmation of route selection and for determining the water balance that will determine the extent of the future phases of the MDP.

Considering the actual purpose and future needs for water management of the Mahaweli System, an overarching modelling tool is being developed as a 'Mahaweli System Operations Model', which will comprise several different numerical models serving specific purposes as part of an integrated DSS. This model will be an important contributor to sound water management by MASL and DOI.

Following a comprehensive search for suitable software the following selections were made.

Water allocation model: RiverWare (current version 7.0).

- Rainfall-runoff model: Soil and Water Assessment Tool (SWAT) (current version SWAT2012 revised 637) incorporating crop water-demand module. 

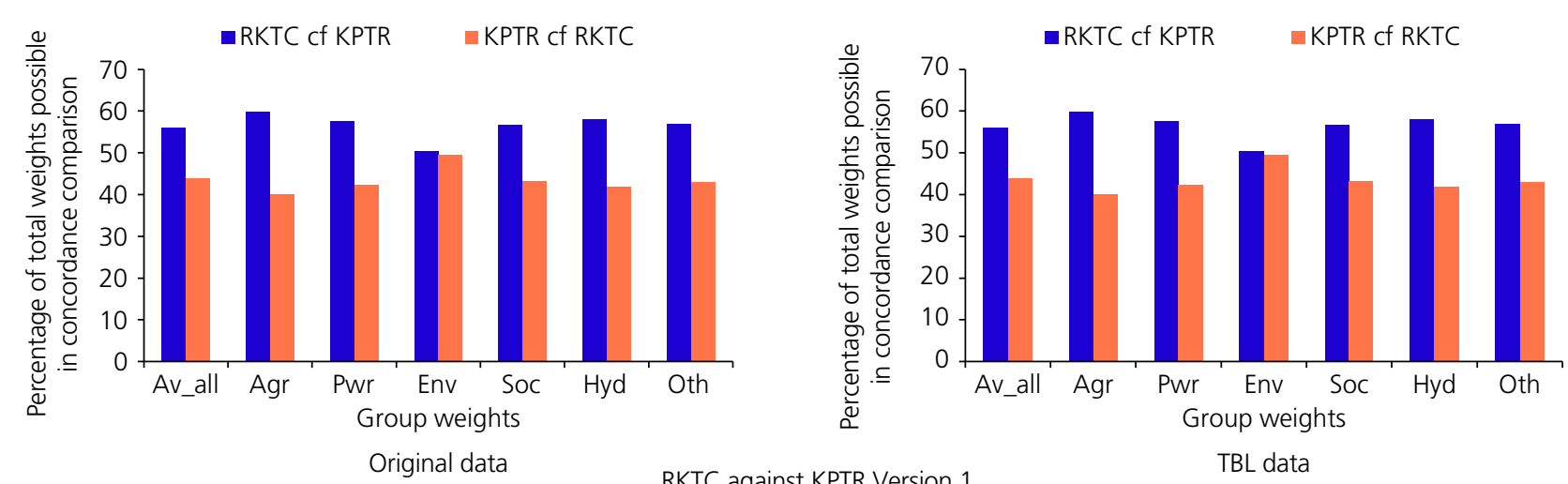

RKTC against KPTR Version 1

TBL data
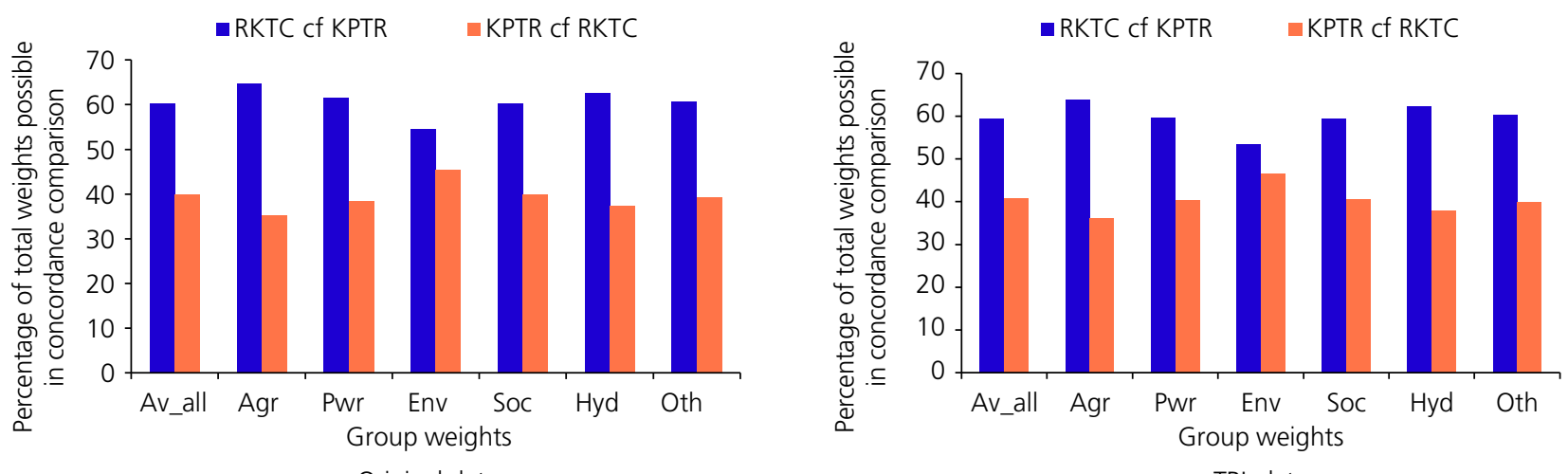

Original data

RKTC against KPTR Version 2

TBL data
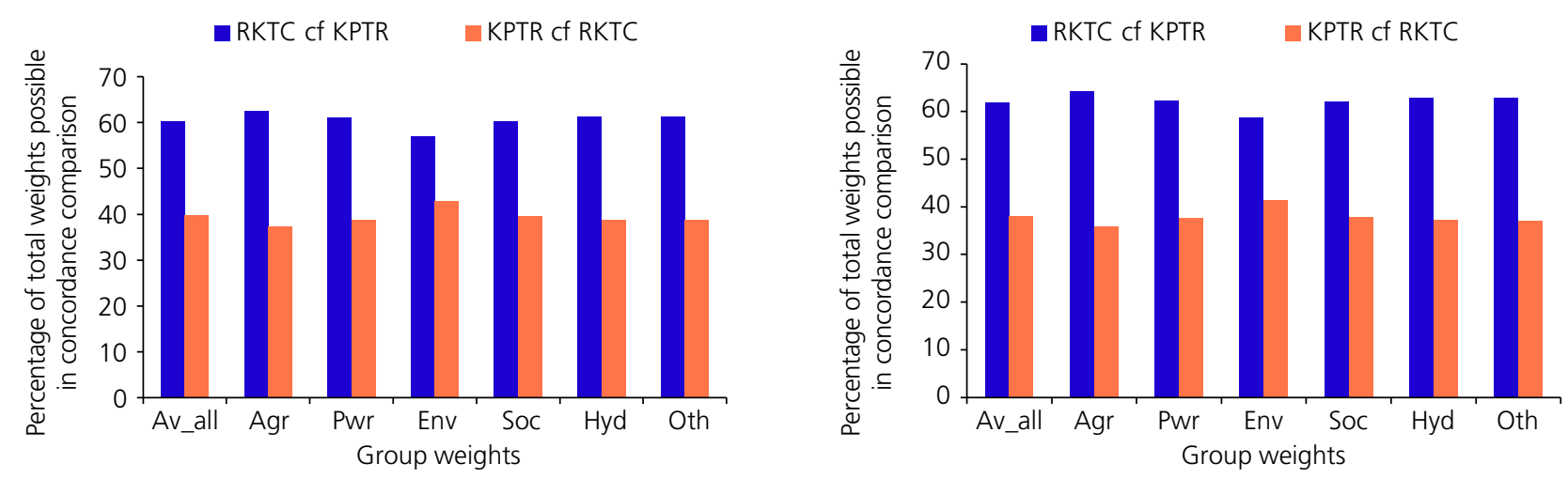

RKTC against KPTR Version 3

TBL data

Figure 6. Comparison of MCA results for route selection

\subsubsection{RiverWare water allocation model}

Figure 7 shows a schematic layout of the future infrastructure derived from RiverWare, which is a river system modelling tool for operational decision making, responsive forecasting, operational policy evaluation, system optimisation, water accounting, water rights administration and long-term resource planning. The wide range of applications is made possible by a choice of computational time steps ranging from $1 \mathrm{~h}$ to 1 year. It has the capability to model

- hydrology and hydrologic processes of reservoirs, river reaches, diversions, distribution canals, consumptive uses, groundwater interaction and conjunctive use 


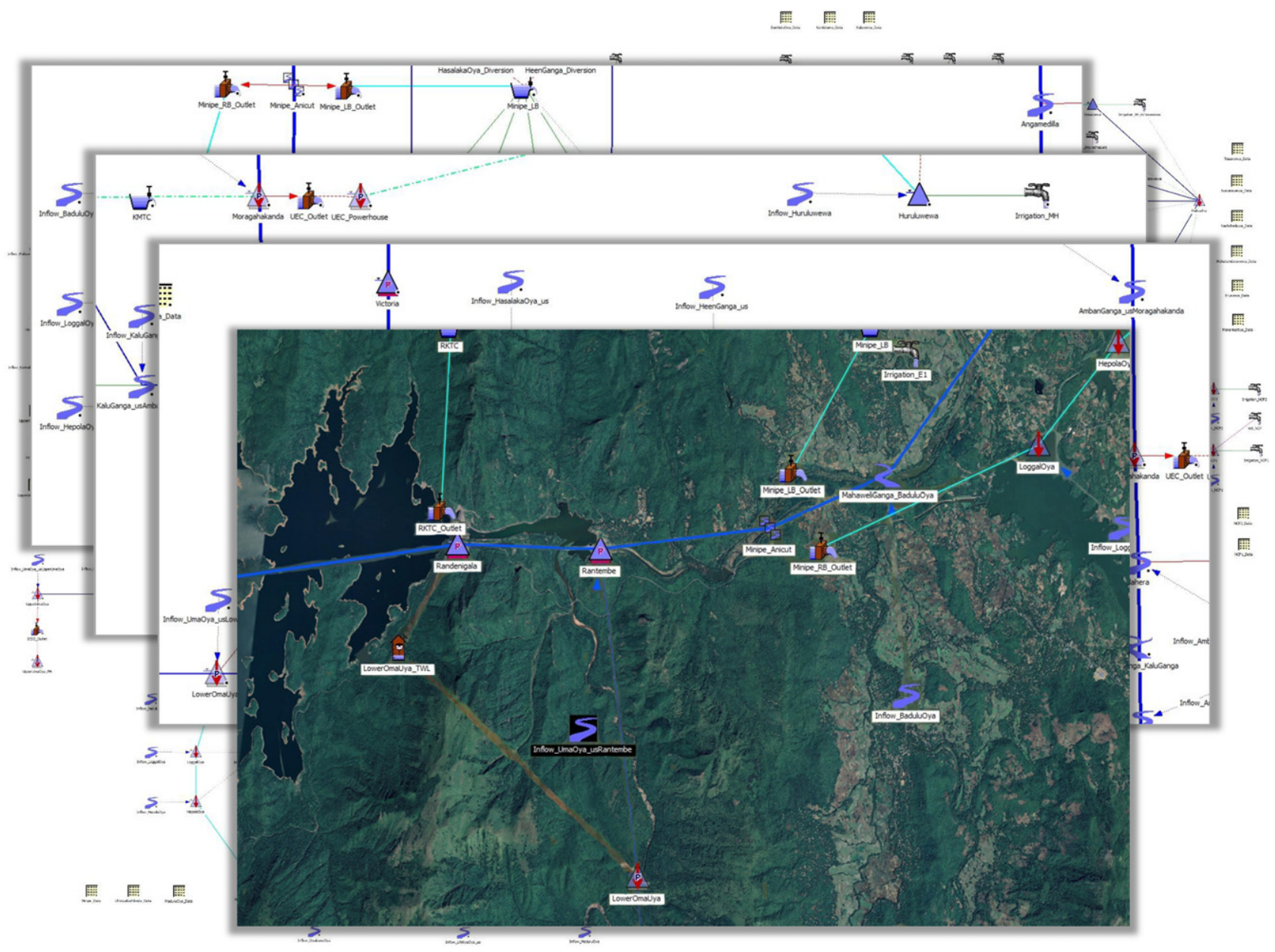

Figure 7. Schematic layout of RiverWare model

- water quality including total dissolved solids, dissolved oxygen and temperature

- hydropower production and energy uses

- water rights, water ownership and water accounting transactions.

The model simulates by solving the governing equations on each object and propagating values by way of links. Rule-based simulation provides a means for modelling driven by logical policy statements rather than explicitly specified input values for operations such as reservoir releases, storages, diversions and so on. In general, the operating policies, called rules, contain logic for operating the system based on hydrologic conditions, time of year, demands and numerous other considerations, such as hydropower demands in the network having priority over irrigation demands or vice versa during the period under consideration.

Priority water rights allocations are executed by a rule function that solves the global problem of allocating water designated as 'allocable flow' according to priority dates for storage rights, diversion rights and in-stream flow rights. The solver visits all water rights (storage, diversion and in-stream flow rights) that are linked to that supply chain in priority order as described above. The solver finds the allocation and returns the entire set of values to the rule. In doing so, the solver considers legal constraints such as annual accrual limits and daily maximum diversion rates, as well as physical constraints such as the sizes of conservation pool and of diversion structure.

\subsubsection{Soil and Water Assessment Tool rainfall-runoff model}

The SWAT model is a well-known tool for modelling the hydrological cycle. The cycle is climate driven and provides moisture and energy inputs, characterised by daily precipitation, maximum/ minimum air temperature, solar radiation, wind speed and relative humidity, which control the water balance. SWAT can read these observed data directly from files or generate simulated data at runtime from observed monthly statistics. Hydrological 
processes simulated by crop growth, soil water and groundwater modules in SWAT include canopy storage, surface runoff, infiltration, evapotranspiration, lateral flow, tile drainage, redistribution of water within the soil profile, consumptive use through pumping (if any), return flow, and recharge by seepage from surface water bodies, ponds and tributary channels (Arnold et al., 2012).

Watersheds are divided into multiple sub-watersheds, which are then further subdivided into hydrologic response units (HRUs) that consist of homogeneous land use, management, topographical and soil characteristics. The HRUs are represented as a percentage of the sub-watershed area and may not be contiguous or spatially identified within a SWAT simulation. In other words, the HRU is the smallest element that combines different land uses and soil types by overlaying their spatial maps. HRU level inputs are inputs that can be set to unique values for each HRU in the watershed. All processes such as surface runoff, potential evapotranspiration, lateral flow, percolation and soil erosion are carried out for each HRU. Sub-basin level inputs are inputs set at the same value for all HRUs in the sub-basin. An example of sub-basin level data is information on rainfall and temperature. The same rainfall and maximum and minimum temperature are used for all HRUs within that sub-basin.

Runoff volume is computed using a modification of the 'Soil Conservation Service (SCS) curve number' method (SCS, 1972; USDA, 1986). The curve number varies non-linearly with moisture content of the soil. The model computes evaporation from soils and plants separately. Potential soil water evaporation is estimated as a function of potential evapotranspiration and leaf area index.

Figure 8 shows the watershed identified for rainfall-runoff calculations in the MDP area. Daily rainfall records have been analysed and quality-controlled over a total period of 40 years to provide a reliable database, together with the other SWAT parameters (temperature, land use, soil properties, digital elevation model) of daily inflows to the RiverWare model. Calibration of each HRU requires hundreds of runs that vary parameters in turn until a reasonable match is reached with available discharge records. Where these are not available, parameters from similar HRUs are used.

Following final calibration and testing, the combined model will form a comprehensive instrument for confirming transfer route selection, derivation of water balance, and eventually for supporting decision-making during operations as the increasingly complex physical infrastructure is constructed in stages.

\section{Productivity and management improvements}

In addition to bulk water transfer, the MWSIP will include two consulting packages aimed at improved water management. Since neither has yet commenced they are described only briefly here. The first, 'Improving System Efficiencies and Water Productivity' (ISEWP), will recommend on-farm and system-wide physical and management improvements based on the results of pilot trials in three different parts of the country. 'Strengthening Integrated Water Resources Management' (SIWRM), the second package, will recommend programmes for institutional strengthening as well as for modernising policy and governance frameworks.

\section{Communications}

Clear communication of the MDP's aims and how they are to be achieved is a pre-condition for pre-empting resistance to the programme's implementation. Public concerns must be taken seriously. Various initiatives are being adopted to this end. A strategic communications programme has been formulated and is regularly updated. Grievance redress mechanisms have been set up with easy access by the public through a variety of different channels. Workshops are held regularly with representatives of a broad spectrum of stakeholders, including those opposing the programme's implementation.

Information dissemination is being achieved through public relations events, radio and television broadcasts and the preparation of a photographic and video diary of the construction works. High-quality information brochures have been produced for distribution at suitable locations and events.

A comprehensive website has been set-up and can be viewed at MWSIP (2018). In addition social media platforms are being regularly updated with information about the programme. Both media offer opportunities for lodging grievances and submitting feedback.

\section{Conclusions: lessons learned}

The MWSIP is a long-term programme of interventions, which has been under preparation for many years. Implementation of the programme itself began with the setting up of the PMU and PIUs and the recruitment of the PMDSC at the end of 2015. Given the time frame for the scale of foreseen interventions, the programme is still in its inception.

Experience to date has shown the importance, alongside the exercising of high-quality levels of technical expertise, of raising public awareness, attempting to dispel false fears through clear communication of programme objectives and methodologies, and obtaining consensus through highly participative stakeholder consultations well in advance of major decisions. Stakeholders' perceptions of a better future are sometimes very different from one another, and gaining consensus through intensive communication efforts is essential to reducing resistance to change. Where some are negatively 
Energy, land and water nexus in

Sri Lanka's Mahaweli basin

Chegwin and Kumara

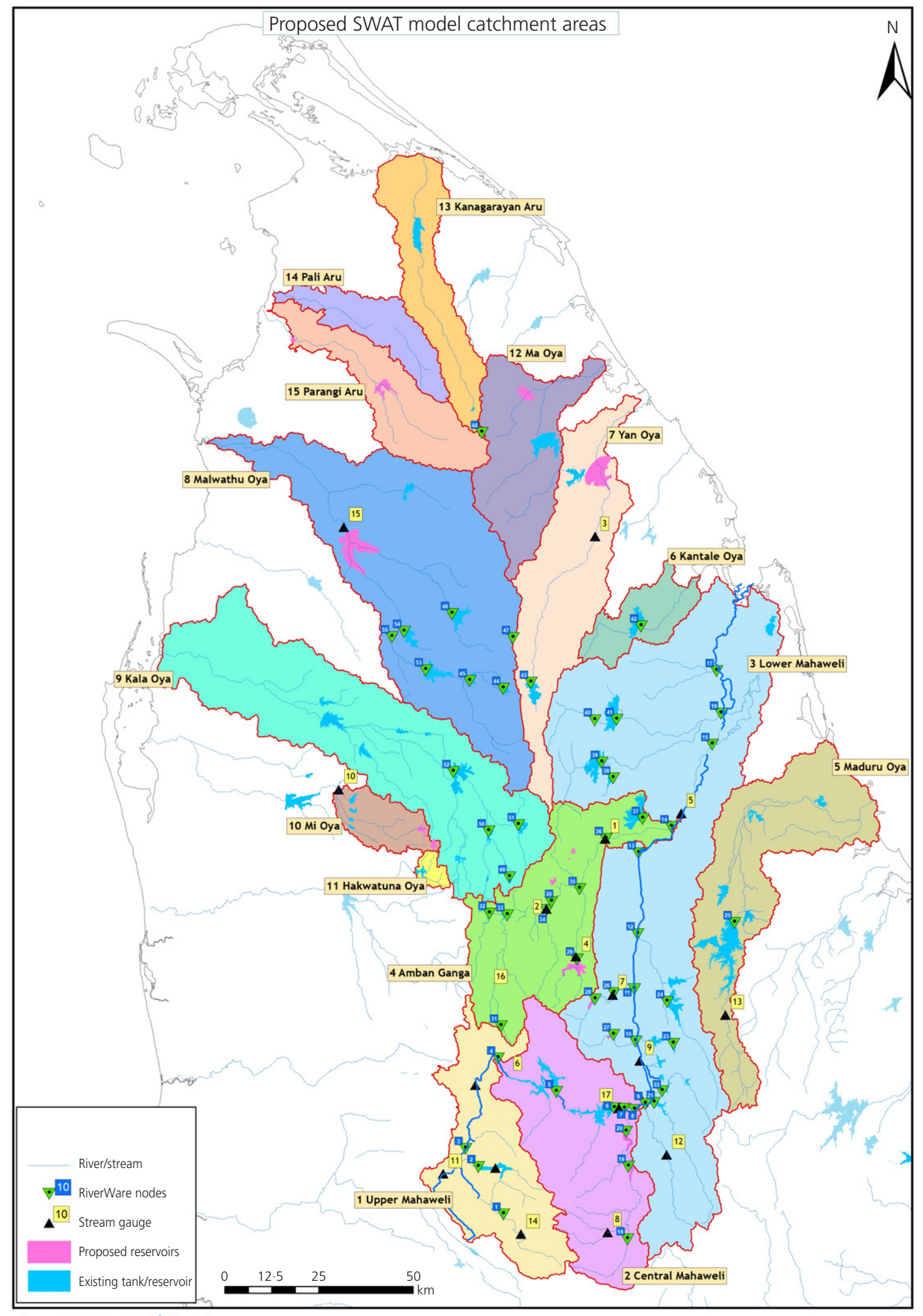

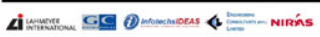

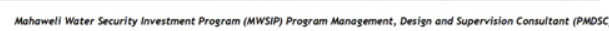

Figure 8. SWAT watersheds. A full-colour version of this figure can be found on the ICE Virtual Library (www.icevirtuallibrary.com) 
impacted by the interventions, they must be appropriately compensated and the impacts mitigated. A process of stakeholder concern analysis, using multiple criteria identified and assigned varying degrees of importance by the stakeholders, has been adopted to increase transparency and acceptance, and to seek consensus on the way forward. A comprehensive mathematical DSS is being constructed to assist decision makers with planning and with real-time operations decisions on water allocation among competing uses.

Completion of the MDP will require not only construction of massive amounts of physical infrastructure. A major change management effort and reorientation of stakeholders towards stewardship of precious water resources will be required to facilitate the implementation of the programme and the achievement of its economic, social and environmental objectives through more intensive and improved water management.

\section{Acknowledgements}

The authors acknowledge the work of the staff of their respective teams and that of the officers of the Asian Development Bank, without which it would not have been possible to write this paper.

\section{Appendix 1: Summary of assessment criteria}

\begin{tabular}{|c|c|}
\hline Number & Criterion \\
\hline 1 & Presence of the critical/protected habitats/species \\
\hline 2 & Extent of the loss of critical habitats (ha) \\
\hline 3 & Impact on aquatic habitats due to change in hydrology (species density changes/water flow) \\
\hline 4 & Habitat fragmentation (number) \\
\hline 5 & Presence of species richness (number of species/ha) \\
\hline 6 & Presence of critical species (number) \\
\hline 7 & Presence of restricted range species (yes/no) \\
\hline 8 & Impact on human-wildlife conflict (number of elephant displacement/number of elephant deaths) \\
\hline 9 & Number of families affected due to human-elephant conflict \\
\hline 10 & Presence of elephant corridors/future corridors \\
\hline 11 & Presence of protected areas (ha) \\
\hline 12 & Capital cost (US\$) \\
\hline 13 & Internal rate of return (IRR) \\
\hline 14 & Operation and maintenance cost (US\$) \\
\hline 15 & Impact on groundwater level $(\mathrm{m})$ \\
\hline 16 & Potential impact on the ground water quality \\
\hline 17 & Land slide potential (using National Building Research Organisation maps) \\
\hline 18 & Impact on wildlife migratory routes (animals other than elephants - i.e. leopard) \\
\hline 19 & Influence on human settlements (number of families to be displaced) \\
\hline 20 & Impact on downstream uses and existing riparian rights (number) \\
\hline 21 & Ability to achieve target irrigated area (ha/million $\mathrm{m}^{3}$ (MCM)) \\
\hline 22 & Ability to achieve water transfer \\
\hline 23 & Reliability of supply (\%) \\
\hline 24 & Impact on flood control (annual recovery cost in terms of rupees) (source of data-disaster management centre) \\
\hline 25 & Loss of the power generation (GWh) \\
\hline 26 & Loss of peak power generation potential (MW) - include cost comparison \\
\hline 27 & Technical feasibility of expanding Victoria (yes/no) \\
\hline 28 & Technical difficulty of constructing proposed infrastructure \\
\hline 29 & Additional carbon dioxide emission due to extra generation of thermal power (tons of carbon dioxide $\left(\mathrm{CO}_{2}\right)$ ) \\
\hline 30 & Acquisition of lands for development (ha) \\
\hline 31 & Potential area loss of mining (ha) \\
\hline 32 & Archaeological sites (number) \\
\hline 33 & Manmade structures to be affected (infrastructure) (number of structures) \\
\hline 34 & Safety and stability of the water-retaining structure (safety factor) to relative structural safety \\
\hline 35 & Increase living standards of farmer communities (monthly income in rupees) \\
\hline 36 & Generation of new employments (number) \\
\hline 37 & Allocation of priority resources \\
\hline 38 & Relative utilisation of existing assets (low/moderate/high) \\
\hline 39 & Ability to get community consent and local government approval \\
\hline 40 & Distribution of CKD incidents (number) \\
\hline 41 & Interference with other government projects/policies \\
\hline
\end{tabular}




\section{Appendix 2: Assessment of water and power criteria}

\section{A2.1 Water and power criteria}

There are seven stakeholder identified criteria related to water transfer and power generation, which are broadly categorised as being 'economic'. These criteria (numbered as in Appendix 1) are as follows.

Number 21: the ability to achieve the target irrigated area (ha/MCM).

Number 22: ability to achieve water transfer.

Number 23: reliability of supply (\%).

Number 25: loss of power generation (GWh).

Number 26: loss of peak power generation potential (MW).

Number 27: technical feasibility of expanding Victoria

(power station), yes/no.

Number 29: additional carbon dioxide emission due to extra generation of thermal power (tons of carbon dioxide).

The simulation study provides quantitative assessment of the performance of the route options in transferring the required water volumes to meet MWSIP requirements, and the reliability of these transfers. It also provides estimates of power generation within the Mahaweli hydropower cascades and reliability to meet peaking durations. This information in turn forms the basis for scoring the listed criteria and determining the feasibility for expanding the Victoria hydropower station for peaking operation.

Several simulation runs were carried out for both routes. These runs determined the water transfers, both annual volumes and reliability of transfer volumes, and energy generation, both annual and peaking. For assessment of peaking, simulations were run to determine the reliability to meet daily peaking durations of 3 and $5 \mathrm{~h}$ in the main Mahaweli hydropower cascade (Victoria and Randenigala), with and without the expansion of the Victoria power station - there is a proposal for the expansion (doubling) of the installed capacity of the Victoria power station to facility peaking operation. Table 1 lists a summary of the runs.

\section{A2.2 Comparison of simulation results of two options}

Simulation results of the two route options are compared in the following sub-sections in the areas reliability of drinking water supply and of irrigation water, peaking operations,

Table 1. Simulation runs carried out for different scenarios

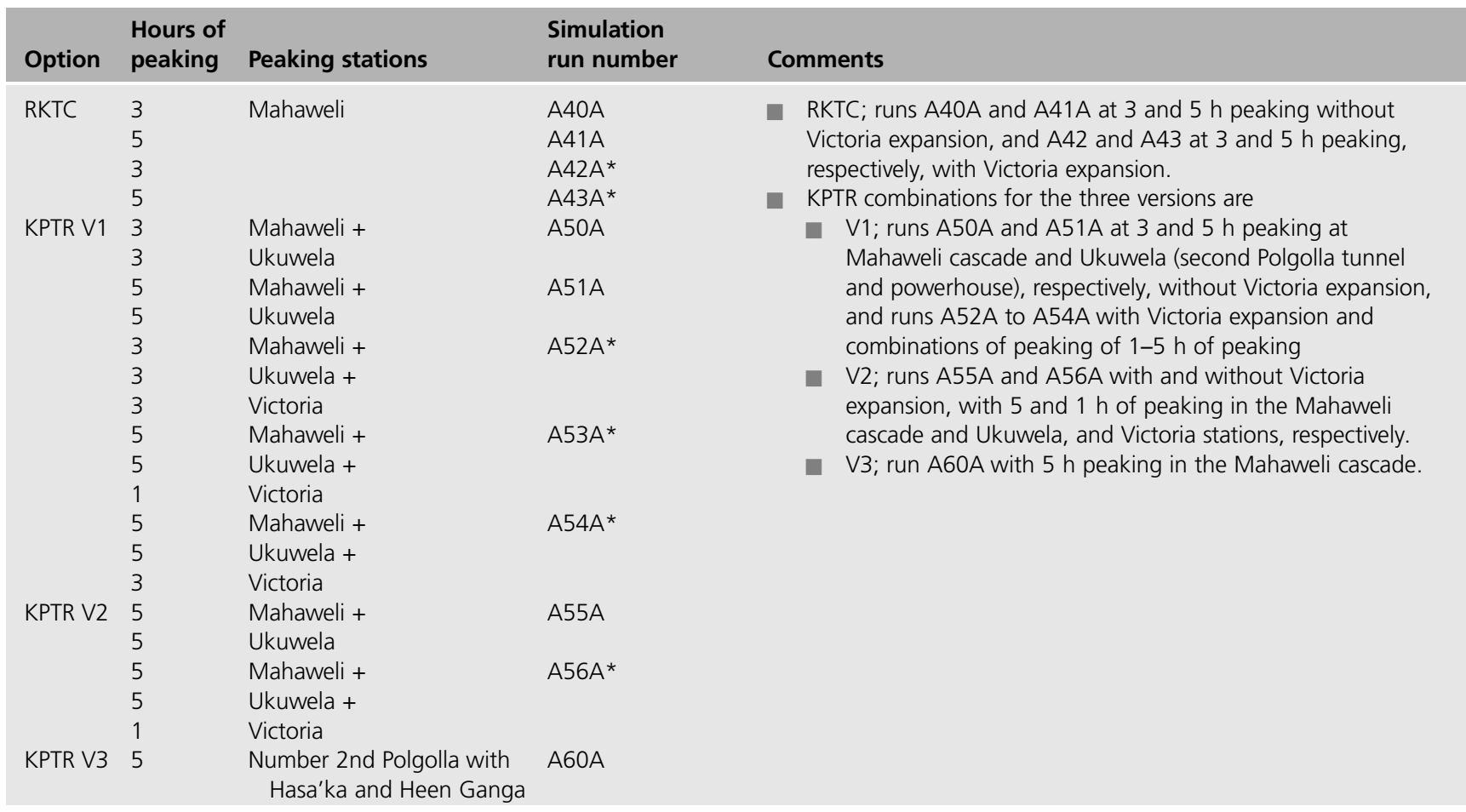

Notes: Mahaweli refers to existing system with Kotmale, Victoria, Randenigala, Rantembe, Ukuwela, Bowatenna, UEC, Moragahakanda, Kalu Ganga Ukuwela refers to new plant of $40 \mathrm{MW}$

Victoria refers to new plant of $210 \mathrm{MW}$

Victoria expansion is shown as *

V1, V2 and V3 refer to the three versions of the KPTR 
major diversions, energy generation and macro-system reservoir behaviour.

The government's policy is to give highest priority to supply drinking water requirement, second priority is for the irrigation and peak power generation is the third priority. These priorities were adopted in the study as a basis for required levels of water transfers and supply reliability.

In this study, Mahaweli system is analysed for energy generation in isolation of other hydropower and thermal systems and hence, a reliability of $90 \%$ is selected for comparison purposes. Otherwise, the overall system reliability for peaking should be $100 \%$.

The definition of the failure criteria adopted for irrigation is as follows.

- Irrigation failure: Yala deficits $>$ or $=5 \%$ of total Yala demand is allowed $20 \%$ of the simulation period.

- Significant irrigation failure: Yala deficit $>$ or $=10 \%$ of Yala demand is allowed $10 \%$ of the simulation period.

- Total irrigation failure: Yala deficits $>$ or $=20 \%$ of Yala demand is allowed $5 \%$ of the simulation period.

\section{A2.3 Comparison of irrigation reliability}

It is estimated that around 900 million $\mathrm{m}^{3}$ of excess water are available in the main Mahaweli to divert to the northern dry zone for drinking water requirements and for irrigated agriculture. For this volume, the reliability of irrigation must be established in both options for different configurations. Only in V2 could the irrigation reliability of KPTR be violated by restricting the pumping at the lower Mahaweli to be the same as for RKTC.

The results showed that RKTC achieves virtually full reliability over the simulation period, for both 3 and $5 \mathrm{~h}$ power peaking. The KPTR V1 and V3 also have high levels of reliability (due principally to the additional pumping from the lower Mahaweli), which effectively meets any shortfall in supply. However, for KPTR V1, for which there is no additional pumping, there are several irrigation failures on several irrigation systems, principally those of the North Central Province, which therefore would lead to constraints on productivity in these systems in some years.

\section{A2.4 Energy generation}

The 5 year average annual historic energy generations at major stations of Mahaweli are compared with the results of simulation of key scenarios and are depicted in Table 2. Table 3

Table 2. Energy generation comparison with historic data (GWh/year)

\begin{tabular}{|c|c|c|c|c|c|c|c|c|c|}
\hline \multirow[b]{2}{*}{ Energy generation in GWh at } & \multirow{2}{*}{$\begin{array}{c}\text { KPTR V3 } \\
\text { A60A }\end{array}$} & \multicolumn{2}{|c|}{ KPTR V3 } & \multicolumn{2}{|c|}{ KPTR V1 } & \multicolumn{2}{|c|}{ RKTC } & \multirow[b]{2}{*}{ Last 10 years } & \multirow[b]{2}{*}{ Last 5 years } \\
\hline & & A56A* & A55A & A54A* & A51A & A43A* & A41A & & \\
\hline Kotmale & 483 & 462 & 478 & 468 & 479 & 436 & 438 & 400 & 440 \\
\hline Victoria & 552 & 456 & 465 & 491 & 469 & 693 & 694 & 644 & 745 \\
\hline Randenigala & 308 & 280 & 275 & 326 & 276 & 325 & 313 & 320 & 361 \\
\hline Rantembe & 149 & 137 & 135 & 155 & 136 & 139 & 136 & 170 & 182 \\
\hline Polgolla & 237 & 261 & 261 & 231 & 260 & 155 & 161 & 152 & 145 \\
\hline Bowatenna & 117 & 136 & 136 & 114 & 135 & 64 & 67 & 54 & 55 \\
\hline Total (Mahaweli) & 1844 & 1732 & 1751 & 1768 & 1755 & 1811 & 1808 & 1740 & 1930 \\
\hline
\end{tabular}

Note: KPTR V2 refers to the same pumping facilities as of RKTC

KPTR V3 refers to a hybrid combination of RKTC and KPTR

Victoria expansion is shown as *

Last 10 years refer to annual average values from 2004 to 2013 and 5 years refer to those of 2009-2013

Table 3. Loss of energy and peaking power

\begin{tabular}{|c|c|c|c|c|c|c|c|c|}
\hline \multirow{2}{*}{$\begin{array}{l}\text { Simulation run number } \\
\text { Station }\end{array}$} & \multicolumn{2}{|c|}{ A41A (RKTC) } & \multicolumn{2}{|c|}{ A51A (KPTR V1) } & \multicolumn{2}{|c|}{ A55A (KPTR V2) } & \multicolumn{2}{|c|}{ A60A (KPTR V3) } \\
\hline & \multicolumn{2}{|c|}{ Energy power: \% } & \multicolumn{2}{|c|}{ Energy power: \% } & \multicolumn{2}{|c|}{ Energy power: \% } & \multicolumn{2}{|c|}{ Energy power: \% } \\
\hline Kotmale & 0 & 0 & -9 & -6 & -9 & -6 & -10 & -7 \\
\hline Ukuwela & -11 & -11 & -80 & -80 & -80 & -80 & -63 & -63 \\
\hline Victoria & 7 & 7 & 37 & 35 & 38 & 36 & 26 & 31 \\
\hline Randenigala & 13 & 13 & 23 & 24 & 24 & 24 & 15 & 19 \\
\hline Rantembe & 26 & 26 & 25 & 26 & 26 & 27 & 18 & 23 \\
\hline Bowatenna & -22 & -22 & -145 & -145 & -148 & -148 & -112 & -113 \\
\hline Mahaweli & 6 & 6 & 9 & 14 & 9 & 14 & 4 & 9 \\
\hline
\end{tabular}


shows results of simulation runs of KPTR and RKTC with $5 \mathrm{~h}$ of peaking. Energy and peaking power losses occur at Victoria and Randenigala stations, which is a critical issue for the CEB. However, the losses of energy and power at these two stations are compensated by gains at the Kotmale station in the case of the KPTR option.

\section{A2.5 Environmental considerations}

The method used in determining environmental flow is based purely on hydrological data and on subjective assessments of water availability at system exit. As per the guidelines of Tennant (1976) for the environmental flow requirement to achieve the required level of ecological status for good habitat, $40 \%$ of mean annual flow (MAF) should be released during the wet season and $20 \%$ of that during the Yala.

The environmental releases were imposed as fixed constraints at Polgolla, Minipe and PS1, for which mean monthly flows (MMF) were established in order to check whether they satisfy the $20 \%$ MAF rate requirement for maintaining good habitat during dry weather flows. Twenty per cent of MAF corresponds to $16 \cdot 15 \mathrm{~m}^{3} / \mathrm{s}$. As per the mean monthly flows there are three violations (June-August) of $20 \%$ of MAF requirements while downstream flow in June is less than $10 \%$ of MAF, which corresponds to fair and degrading habitat.

Table 4 depicts the total water availability at Kandakadu (system outlet), which consists of system A, irrigation requirements, drinking water supply (WS) requirements of Trincomalee and downstream flows at Kandakadu diversion

Table 4. Comparison of exceedance flows at system exit (Kandakadu)

\begin{tabular}{|c|c|c|c|c|c|}
\hline \multirow[b]{2}{*}{ Month } & \multicolumn{5}{|c|}{$80 \%$ exceedance flows at system exit: $\mathrm{m}^{3} / \mathrm{s}$} \\
\hline & Target & RKTC & KPTR V1 & KPTR V2 & KPTR V3 \\
\hline October & $32 \cdot 30$ & $36 \cdot 17$ & $34 \cdot 64$ & $36 \cdot 30$ & $40 \cdot 90$ \\
\hline November & $32 \cdot 30$ & 55.92 & $62 \cdot 53$ & $63 \cdot 60$ & $47 \cdot 20$ \\
\hline December & $32 \cdot 30$ & $96 \cdot 53$ & $113 \cdot 55$ & $105 \cdot 80$ & $94 \cdot 90$ \\
\hline January & $32 \cdot 30$ & $131 \cdot 78$ & $133 \cdot 94$ & $132 \cdot 50$ & $112 \cdot 10$ \\
\hline February & $32 \cdot 30$ & $49 \cdot 47$ & $55 \cdot 89$ & $60 \cdot 60$ & $45 \cdot 10$ \\
\hline March & $32 \cdot 30$ & $49 \cdot 99$ & $48 \cdot 08$ & $53 \cdot 90$ & $44 \cdot 60$ \\
\hline April & $16 \cdot 15$ & $46 \cdot 56$ & $45 \cdot 61$ & $54 \cdot 20$ & $44 \cdot 80$ \\
\hline May & $16 \cdot 15$ & $25 \cdot 38$ & $22 \cdot 42$ & 31.90 & $14 \cdot 70$ \\
\hline June & $16 \cdot 15$ & 11.08 & 8.99 & $14 \cdot 60$ & $5 \cdot 20$ \\
\hline July & $16 \cdot 15$ & $16 \cdot 75$ & 8.59 & $16 \cdot 30$ & $5 \cdot 20$ \\
\hline August & $16 \cdot 15$ & $17 \cdot 38$ & $13 \cdot 47$ & $18 \cdot 10$ & $11 \cdot 50$ \\
\hline September & $16 \cdot 15$ & $22 \cdot 02$ & $16 \cdot 74$ & $23 \cdot 10$ & $16 \cdot 80$ \\
\hline $\begin{array}{l}\text { Flow rates le } \\
\text { Flow rates le } \\
\text { Flow rates le }\end{array}$ & $\begin{array}{l}\text { than } 4 \\
\text { than } 2 \\
\text { than } 10\end{array}$ & $\begin{array}{l}\% \text { MAF a } \\
\% \text { MAF a } \\
\% \text { MAF a }\end{array}$ & $\begin{array}{l}\text { shown } t \\
\text { shown t } \\
\text { shown t }\end{array}$ & & \\
\hline
\end{tabular}

point as per the KPTR V3 (simulation run A60A). When 20\% exceedance flows at the system exit are examined for the RKTC and KPTR options there is only one violation each for RKTC and KPTR V2 corresponding to 20\% MAF, whereas there are three violations in KPTR V1 corresponding to $20 \%$ MAF, and there are four violations in KPTR V3 corresponding to $20 \%$ of MAF, of which two are less than $10 \%$ MAF. Nevertheless, KPTR V2 does not satisfy the irrigation demand in the NCPCP. RKTC could therefore be ranked first of all four options in meeting the downstream requirements. Nevertheless, in all versions of the KPTR if lower Uma Oya reservoir is considered with diversion of its water to Randenigala all these violations could be minimised, although incurring additional cost to the project.

\section{A2.6 Summary of observations}

The key observations and conclusions of the simulation study of the route options are as follows.

(a) Both options ensure the reliability of irrigation, water supply and minimum hours of peaking at hydropower stations except that KPTR V2 does not satisfy the irrigation demand in the North Central Province.

(b) The relative losses of peaking power at Victoria and Randenigala are 28 and $11 \%$ under KPTR. They are 35 and $24 \%$, respectively, using the last 5 year average figures.

(c) The RKTC option ensures diversion of $70 \%$ of the total requirements of the northern dry zone under gravity and 30\% through pumping, whereas the KPTR option ensures only $60 \%$ under gravity with $40 \%$ requiring pumping. In both options, the quantity of diversion to the northern dry zone was ensured.

(d) Three hours of peaking in Mahaweli system hydropower stations retain the required reliability of water for irrigation and drinking purposes. Five hours of peaking requires more water to pass through powerhouses over and above the irrigation needs, resulting in reduced water levels in the most upstream reservoirs and high water levels at Randenigala.

(e) Raising Kotmale is an asset not only for the KPTR option but also to the existing system. The lower reservoir trajectory with $5 \mathrm{~h}$ of peaking in the RKTC option could be avoided if Kotmale was heightened.

( $f$ ) Victoria expansion becomes almost impossible with the KPTR option.

(g) The river reach between Kotmale power house and Polgolla diversion barrage would become more vulnerable due to peaking operations of Kotmale and the proposed Moragolla hydropower station, especially during lean periods. The peaking discharge of $159 \mathrm{~m}^{3} / \mathrm{s}$ 
(Kotmale $=3 \times 38 \mathrm{~m}^{3} / \mathrm{s}$ and Moragolla $45 \mathrm{~m}^{3} / \mathrm{s}$ ) being released during $2 \mathrm{~h}$ in the morning and $3 \mathrm{~h}$ in the evening may become threatening to the thousands of water users along this river reach and several drinking water abstraction points. The city of Gampola and its suburbs having high population density also lie within this river reach. This situation is more prominent in the KPTR option.

(h) The river reach between Ukuwela power station and Bowatenna reservoir would also have to face similar situation due to increased power releases $\left(2 / 56 \mathrm{~m}^{3} / \mathrm{s}\right)$ during peaking hours. The existing and most upstream mini-hydropower stations would be deprived of increased power generation potential at Ukuwela due to limited turbine capacities. All mini-hydropower stations would also be affected due to increased tail water levels. (i) With respect to downstream water users' requirements, both options ensure the irrigation water of systems A, B, $\mathrm{C}$ and $\mathrm{E}$, drinking water requirements at Manampitiya of Trincomalee district and environmental flow requirements at Minipe and PS1.

(j) V1 and V3 of the KPTR option violate the environmental flow requirements at Kandakadu in the downstream flood plain. Nevertheless, this could be minimised through diversion of Uma Oya flows to Randenigala as proposed in the RKTC option and releasing during the lean period.

\section{A2.7 Relevance to the multi-criteria analysis}

A comparison of findings of the study on KPTR and RKTC is depicted in Table 5. Implementation of the Victoria expansion project becomes unfeasible with KPTR.

Table 5. Comparison of the findings of the water balance study on route selection relevant to the MCA

\begin{tabular}{|c|c|c|c|c|c|c|}
\hline Number & Criterion & \multicolumn{2}{|l|}{ KPTR } & \multicolumn{3}{|c|}{ RKTC } \\
\hline 20 & $\begin{array}{l}\text { Impact on downstream users and existing } \\
\text { riparian rights }\end{array}$ & \multicolumn{2}{|c|}{$\begin{array}{l}\text { (b) Thirty per cent reduction in } \\
\text { energy generation at Victoria } \\
\text { (c) Average annual water level in } \\
\text { major reservoirs is low } \\
\text { (d) More than one violation of } \\
\text { environmental flow at } \\
\text { Kadakadu over the year }\end{array}$} & $\begin{array}{l}\text { (a) } \\
(b) \\
(c) \\
\text { (d) }\end{array}$ & \multicolumn{2}{|c|}{$\begin{array}{l}\text { No violation } \\
\text { Same as at present } \\
\text { Average annual water level in } \\
\text { major reservoirs is high } \\
\text { One marginal violation of } \\
\text { environmental flow }\end{array}$} \\
\hline 21 & $\begin{array}{l}\text { The ability to achieve target } \\
\text { irrigated area }\end{array}$ & \multicolumn{2}{|c|}{ Same } & \multicolumn{3}{|c|}{ Same } \\
\hline 22 & Ability to achieve water transfer & \multicolumn{2}{|c|}{$\begin{array}{l}\text { Possible with higher capital and } \\
\text { operation and maintenance costs }\end{array}$} & \multicolumn{3}{|c|}{ Possible } \\
\hline 23 & Reliability of supply & \multicolumn{2}{|c|}{$\begin{array}{l}\text { (a) Less than } 80 \% \text { for irrigation } \\
\text { (b) } 100 \% \text { for drinking water }\end{array}$} & $\begin{array}{l}(a) \\
(b)\end{array}$ & \multicolumn{2}{|c|}{$\begin{array}{l}\text { More than } 80 \% \text { for irrigation } \\
100 \% \text { for drinking water }\end{array}$} \\
\hline 25 & Loss of energy generation & \multicolumn{2}{|c|}{$\begin{array}{l}173 \text { GWh: } 9 \% \text { of the last } 5 \text { year } \\
\text { generation }\end{array}$} & \multicolumn{3}{|c|}{$\begin{array}{l}120 \text { GWh: } 6 \% \text { of last } 5 \text { year } \\
\text { average }\end{array}$} \\
\hline 26 & Loss of peak power generation & $\begin{array}{l}\text { 1. Kotmale } \\
\text { 2. Victoria } \\
\text { 3. Randenigala } \\
\text { 4. Rantembe } \\
\text { 5. Polgolla } \\
\text { 6. Bowatenna } \\
\text { 7. Entire Mahaweli } \\
\text { 8. High-head plants }\end{array}$ & $\begin{array}{l}-6 \% \text { (gain) } \\
35 \% \\
24 \% \\
26 \% \\
-80 \% \\
-145 \% \\
14 \% \\
21 \%\end{array}$ & $\begin{array}{l}\text { 1. K } \\
\text { 2. V } \\
\text { 3. R } \\
\text { 4. R } \\
\text { 5. P } \\
\text { 6. B } \\
\text { 7. E } \\
\text { 8. } \mathrm{H}\end{array}$ & $\begin{array}{l}\text { otmale } \\
\text { ictoria } \\
\text { andenigala } \\
\text { antembe } \\
\text { olgolla } \\
\text { owatenna } \\
\text { ntire Mahaweli } \\
\text { igh-head plants }\end{array}$ & $\begin{array}{l}-6 \% \text { (gain) } \\
35 \% \\
24 \% \\
26 \% \\
-80 \% \\
-145 \% \\
14 \% \\
21 \%\end{array}$ \\
\hline 27 & Technical feasibility of Victoria expansion & \multicolumn{2}{|l|}{ Unfeasible } & \multicolumn{3}{|c|}{ Feasible } \\
\hline 29 & $\begin{array}{l}\text { Additional carbon dioxide emission due to extra } \\
\text { generation of thermal power (tonnes) }\end{array}$ & \multicolumn{2}{|l|}{9 units } & \multicolumn{3}{|c|}{6 units } \\
\hline 38 & Relative utilisation of existing assets & \multicolumn{2}{|c|}{$\begin{array}{l}\text { Heightening of Kotmale and } \\
\text { construction of second Polgolla } \\
\text { tunnels represent negative use of } \\
\text { existing assests }\end{array}$} & $\begin{array}{l}\text { (a) } \\
\text { (b) } \\
\text { (c) }\end{array}$ & \multicolumn{2}{|c|}{$\begin{array}{l}\text { Kotmale and Randenigala } \\
\text { storages } \\
\text { Utilisation of upper Uma Oya, } \\
\text { Heen Ganga and Hasalaka } \\
\text { water resources } \\
\text { Use of Kalu Ganga reservoir }\end{array}$} \\
\hline
\end{tabular}




\section{Appendix 3: Assessment of cost criteria}

This appendix addresses two of the criteria categorised as being 'economic' (criteria number as per Appendix 1). These criteria are as follows.

Number 12: capital cost.

Number 14: operation and maintenance (O\&M) cost.

\section{A3.1 Capital and O\&M costs}

The capital and O\&M costs are significant determinants in the choice of routes, both in terms of the MCA process and in the overall programme economics. The information on costs differed between the two routes; for RKTC the most current information was that presented in a pre-feasibility study of 2013, and for the KPTR cost information was largely nonexistent.

The overall approach to establishing a best estimate of current costs for RKTC was to update previous estimates based on current rates for materials and works, and for the KPTR estimates were made for the key components of Kotmale dam heightening, a second Polgolla tunnel and powerhouse and remedial works on the Sudu Ganga, the watercourse downstream of the tunnel. Given the time constraint and scope of the task, the results should be regarded as best estimates for the two routes, which are sufficiently accurate for the relative comparison required for the MCA process. However, values will be replaced by a more detailed estimate during preparation of the feasibility level design.

\section{A3.1.1 RKTC costs}

The general approach was to update costs for the structures as presented in the earlier pre-feasibility study of 2013. This included revision of the unit rates for works and in some cases also the revision of quantities.

The total capital cost for RKTC is approximately US\$911 million, of which US\$261 million is for the transfer tunnels and canals, US\$76 million for the Hasalaka dam and powerhouse, US\$198 million for the Heen Ganga dam and powerhouse and US\$163 million for the lower Uma Oya dam, powerhouse and tunnel. The pumping station PS1, which is not part of the MWSIP investment (but a complementary and integral part of the development of the Mahaweli development) is estimated to cost US\$213 million.

\section{A3.1.2 KPTR costs}

\section{A3.1.2.1 V1 AND V2}

Due to the shortage of information on the cost for the proposed works, the approach adopted for estimating the KPTR costs involved a mixture of updating former studies and estimates using current market rates for similar works.
Table 6. Summary of comparison between route options

$\begin{array}{llccc}\text { Route } & \text { Version } & \begin{array}{c}\text { Capital } \\ \text { cost: } \\ \text { US\$ million }\end{array} & \begin{array}{c}\text { Total } \\ \text { O\&M cost: } \\ \text { US\$ million }\end{array} & \begin{array}{c}\text { Pump } \\ \text { station O\&M: } \\ \text { US\$ million }\end{array} \\ \text { RKTC } & - & 911 & 14.0 & 7 \cdot 4 \\ \text { KPTR } & \text { V1 } & 781 & 14 \cdot 3 & 10 \cdot 5 \\ \text { KPTR } & \text { V2 } & 710 & 11 \cdot 2 & 7 \cdot 4 \\ \text { KPTR } & \text { V3 } & 1004 & 16.9 & 10 \cdot 5\end{array}$

The total capital costs for the KPTR V1 and V2 are approximately US\$781 million and US\$710 million, respectively, with the costs of Kotmale heightening (US\$325 million), the additional Polgolla tunnel (US\$122 million) and bridge/river training works to the downstream watercourse Sudu Ganga (US\$50 million) being common to both. The difference in total cost is accounted for by the different pumping configuration for each of the versions.

\section{A3.1.2.2 KPTR V3}

At the request of the Ceylon Electricity Board (CEB), a variant of the KPTR (referred to as V3) was also examined. It comprises the Kotmale dam heightening, and construction of the Hasalaka and Heen Ganga dams and powerhouses and the section of the transfer tunnel and canal linking to the Kalu Ganga reservoir. The variant excludes the second Polgolla tunnel and powerhouse and the need for remedial works on the Sudu Ganga. It also includes the PSs at the same duty as per the RKTC. Capital costs were estimated at US\$1004 million, comprising US\$325 million for Kotmale heightening, US\$122 million for transfer canals and tunnels, US\$273 million for dams and powerhouses and US\$284 million for the PS.

\section{A3.1.3 Summary}

Table 6 compares capital and O\&M costs of the four route options.

\section{REFERENCES}

Annandale D and Lantzke R (2000) Making Good Decisions: A Guide to Using Decision-Aiding Techniques in Waste Facility Siting. Institute for Environmental Science, Murdoch University, Perth, Australia, p. 14.

Arnold JG, Moriasi DN and Gassman PW (2012) SWAT: model use, calibration, and validation. Transactions of the ASABE 55(4): 1491-1508.

MWSIP (Mahaweli Water Security Investment Program) (2018) http://www.mwsip.lk (accessed 05/02/2018).

Perrone D and Hornberger G (2016) Frontiers of the food-energy-water trilemma: Sri Lanka as a microcosm of tradeoffs. Environmental Research Letters 11(1): 014005.

PMDSC (Program Management, Design and Supervision Consultant) (2017) Strategic Environmental Assessment. PMDSC, Colombo, Sri Lanka, Final Report.

SCS (Soil Conservation Service) (1972) National Engineering Handbook. United States Department of Agriculture (USDA), Soil Conservation Service (SCS), St. Joseph, MI, USA. 


\section{Energy}

Volume 171 Issue EN3
Energy, land and water nexus in

Sri Lanka's Mahaweli basin

Chegwin and Kumara
Tennant DL (1976) Instream flow regimens for fish, wildlife, recreation and related environmental resources. Fisheries 1(4): 6-10.

USDA (United States Department of Agriculture) (1986) Urban Hydrology for Small Watersheds. Technical Release 55 (TR-55), 2nd edn. Natural Resources Conservation Service, Conservation Engineering Division, Washington, DC, USA.

Zeng R, Cai X, Ringler C and Zhu T (2017) Hydropower versus irrigation - an analysis of global patterns. Environmental Research Letters 12(3): 034006, https://doi.org/10.1088/1748-9326/aa5f3f.

\section{How can you contribute?}

To discuss this paper, please email up to 500 words to the editor at journals@ice.org.uk. Your contribution will be forwarded to the author(s) for a reply and, if considered appropriate by the editorial board, it will be published as discussion in a future issue of the journal.

Proceedings journals rely entirely on contributions from the civil engineering profession (and allied disciplines).

Information about how to submit your paper online is available at www.icevirtuallibrary.com/page/authors, where you will also find detailed author guidelines. 